${ }^{1}$ Kalimash BEGALINOVA, ${ }^{2}$ Madina ASHILOVA, ${ }^{3}$ Alibek BEGALINOV

doctor of philosophical science, Al-Farabi Kazakh National University, Almaty, Kazakhstan (kalima910@mail.ru) ORCID: 0000-0001-5575-5142

${ }^{2} \mathrm{PhD}$, Kazakh Ablai Khan University of International Relations and World Languages, Almaty, Kazakhstan. ORCID: 0000-0002-7634-7727

${ }^{3} \mathrm{PhD}$, International University of Information Technologies, Almaty, Kazakhstan ORCID: 0000-0001-7439-221X

\title{
Features of Spiritual and Moral Teaching of Nizami Gyanjevi
}

\begin{abstract}
The article reveals the ethical aspect inherent in the teachings of Nizami Ganjavi. The role and place of the great Azerbaijani poet and thinker in the history of world spirituality are considered. The authors analyze the originality, uniqueness of the poetic creativity of Nizami, who called each person to spiritual and moral self-improvement. He argued that the most important component of a person's being is his soul, which is the bearer of the highest moral qualities - friendship, love, humanity, etc. The main hero of his works is the people, artisans. All the poet's sympathies are on their side. On the example of his poem "Khamsa", such moral categories as good, cruelty, evil, happiness, the meaning of life, etc. are explored. Important importance is given to revealing the personality of the poet-thinker Nizami as a humanist, a subtle psychologist, a great connoisseur of the human soul. It is shown that morality plays the main line in the formation of a person, his spirituality. This is evidenced by the numerous works of Nizami Ganjavi, in which the man of labor, the true bearer of the spirituality and culture of the people, is glorified. It also touches upon other ethical problems set forth in the works of the great thinker. In general, the teachings of Nizami Ganjavi affirm truly humanistic moral principles in society.

Keywords: singer of justice, humanism, "Khamsa", morality, values

${ }^{1}$ Қалимаш БЕГАЛИНОВА, ${ }^{2}$ Мадина АШИЛОВА, ${ }^{3}$ Алибек БЕГАЛИНОВ

\author{
${ }^{1}$ философия ғылымдарының докторы, Әл-Фараби атындағы ҚазҰУ, Алматы, \\ Қазақстан (kalima910@mail.ru) ORCID: 0000-0001-5575-5142 \\ ${ }^{2} \mathrm{PhD}$, Абылай хан атындағы Халықаралық қатынастар және әлем тілдері \\ университеті, Алматы, Қазақстан. ORCID: 0000-0002-7634-7727 \\ ${ }^{3} \mathrm{PhD}$, Халықаралық ақпараттық технологиялар университеті, Алматы, Қазақстан
} ORCID: 0000-0001-7439-221X
\end{abstract}

\section{Низами Гәнжауидің рухани-адамгершілік ілімінің ерекшеліктері}

\section{Андатпа}

Мақалада Низами Гәнжәуидің іліміне тән этикалық аспект қарастырылған. Әзербайжанның ұлы ақыны, ойшылы Низамидің әлемдік руханият тарихындағы рөлі 
мен орны туралы сөз еткен авторлар әр адамды рухани жетілуге және адамгершілік жолында өзін-өзі жетілдіруге шақырған ақынның поэтикалық шығармашылығының өзіндік ерекшелігін, бірегейлігін талдайды. Ол адам болмысының ең маңызды құрамдас бөлігі оның жан дүниесі, ол ең жоғары адамгершілік қасиеттер - достық, сүйіспеншілік, адамгершілік, т.б. иесі болып табылатынын, оның шығармаларының басты кейіпкері - халық, қолөнершілер деп тұжырымдайды. Ақынның «Хамса» поэмасын негізге алып талдау жасаған мақалада ізгілік, қатыгездік, зұлымдық, бақыт, өмірдің мәні және т.б. адамгершілік категориялар зерттелген. Ақын-ойшылдың гуманист, психолог, адам жанының керемет білгірі ретіндегі жеке басын ашуға үлкен мән берілген. Адамгершіліктің адамның, оның рухани болмысының қалыптасуында атқаратын рөлі көрсетілген. Бұған Низами Гәнжәуидің еңбектері дәлел бола алады, Сондай-ақ мақалада ұлы ойшылдың еңбектерінде айтылған басқа да этикалық мәселелерге ғылыми талдау жасалған.

Кілт сөздер: әділеттілік жаршысы, гуманизм, «Хамса», мораль, құндылықтар

Introduction. Unrivaled contribution to the history of world spiritual culture was introduced by such Azerbaijani poets and philosophers as Nizami Ganjiavi. He was philosopher, bearer of spiritual progress of mankind. These individuals should abstract away from everyday mortal life to foresee the future. But as the saying goes, there are no prophets in the own country. Their fate in their homeland was often tragic. This, above all, is about Nizami. However, their words, their foresights did not lose their significance even nowadays. Their entire ideological heritage is run through by the care of the man of labour, belief in inevitability of the triumph of justice and social equality society, in liberation of a man from all forms of exploitation and oppression.

They all recognized the freedom of the human will, glorified man's mind, sharply and critically pertained to many provisions of the Islamic doctrine, expressed doubts about the existence of the afterlife. They fought for the true happiness of people on earth, and in their teachings recognized a man as a supreme value, and a highest goal. Although their humanism was of abstract character, it was notable for extremely general, not specific approach to a man; it was a humanism of thought, not action. However, it was a definite stage in the development of human spirituality. Under the conditions of undivided rule of Islamic theocratic state, religious intolerance, calling for obedience and humility of spiritual thought to the tenets of the Quran and other inspired Islamic sources, the poets and philosophers of the medieval East - Nizami, Nasimi, Füzuli were defending the earthborn happiness of the people instead of happiness in heaven, considering the earthborn human happiness as an absolute value. That way this article important. 
His work is known far beyond the borders of Azerbaijan and the Islamic world. He is a poet of planetary scale. Philosopher works have been translated into many languages of the world, and poem "Khamse" ("Pyateritsa") has been included in the golden fund of world literature. About him was written and is writing thousands and thousands of books, articles, despite the paucity of biographical information about him. Poetry answers are written - imitations of "Khamse". The best known are the "Pyateritsa" of Alisher Navoi and "Pyateritsa" of Amir Khosrov Dehlavi. Each generation reads Nizami in a new way. And this is quite justified. Nizami invaluable merit is that he is "the creator of masks of great human drama which was played after him dozens of times in the East by his talented and sometimes brilliant successors" [1, p.19]. Philosopher and poet Nizami is also a great innovator in the field of literature. He created new, special standard, type of literary work, specific style called by Nizami as "Gharib" (in Persian - a rare, new). In the scientific literature, it is defined as a style of epigrams. His works are full of idioms, aphorisms, which wre transformed into proverbs and sayings. "The language of poems and phymes of Nizami is distinguished in singularity... He introduced new and transparent detailed metaphors and images, created neologisms. Nizami uses various stylistic figures (hyperbole, anaphora), repetitions (mukarrar), allusion, compound words and images, which he combines with the different elements of the story to increase the power of their influence. Nizami style is also different in that he avoids the use of ordinary words to describe the actions, emotions and behavior of his characters" [2].

The purpose of this article is to reveal the role and place of the spiritual and moral teaching of Nizami Ganjavi, which is achieved through a number of tasks related to the analysis of his work "Khamsa". Certainly, Nizami's work is known far beyond the borders of Azerbaijan. He is a poet on a planetary scale. The works of the thinker have been translated into many languages of the peoples of the world, and the poems "Khamsa" ("The Five") entered the golden fund of world literature. Thousands and thousands of books and articles have been written and are being written about him, despite the paucity of biographical information about him. Poetic responses are being written - imitations on "Hamsa". The most famous are "Five" by Alisher Navoi and "Five" by Amir Khosrov Dehlevi. Each generation reads Nizami in a new way. And this is quite justified. The invaluable merit of Nizami is that he is "the creator of the masks of the great human drama, played dozens of times after him in the East by his talented and sometimes brilliant successors" [3, p. 19]. The thinker, poet Nizami is also the largest innovator in the field of literature. He created a new, special standard, type 
of literary work, a specific style, which Nizami called "garib" (from Persian - rare, new). In the scientific literature, it is defined as the style of epigrams. The history of studying the spiritual and cultural heritage of Nizami covers more than one century. His works are multifaceted, replete with idioms, aphorisms that have transformed into proverbs and sayings. As Khalil Yusifli notes, "Nizami's legacy gives rich and indisputable facts and arguments for highlighting ideological tendencies, cultural level, and the Renaissance nature of the views of his time" p.12-13. The famous scientist Jafar Khandan dedicated his life to the work of Nizami. True, from the position of a Soviet researcher, he does not openly express his attitude to the religious and spiritual world of Nizami [4].

Research methods. In the process of studying the teachings of Nizami Ganjavi, a historical and genetic approach was used, which allows reproducing in all its versatility, taking into account all the smallest zigzags and accidents, the era in which the great poet lived and worked. A systematic approach has also found application, which makes it possible to consider the teachings of Nizami as an independent, integral phenomenon in the system of the spiritual culture of the Azerbaijani people. To achieve the goal, other approaches, general theoretical and philosophical methods were used, such as structural-functional, comparative, dialectical, inductive and others.

Results. Nizami wrote his works not only in Azerbaijani language, but Arabic, Persian. The sources say that Nizami knew one of the European languages, but which language - is unknown. Basically, all significant creations and works, Nizami wrote in Persian, and knew it so brilliantly, masterfully that raised it to a new height, using plenty of allegories, parables, and ambiguous words. It should be noted that the Persian language during the reign of the Seljuk was a state-forming language. It was used as a literary language in the vast territory - from India to Asia Minor. According to E. Bertels, as the powerful rulers accepted this language, then an example was shown to all the princes being under their power. The Persian language becomes first as a sign of belonging to the upper class, it is also mandatory for the feudal lord, as the French language was for the Russian aristocrat. But with the improvement of city life, it begins to play a prominent role in the city. This is the international language, which served as the means of communication for all countless people that were a part of the Seljuk state [4, p.16]. In "Pyateritsa", he uses also folk songs. In this respect it should be noted that all his life he collected songs, classified and arranged some of them. In the poem "Khosrov and Shirin", the poet qualifies a lot of different songs in terms of their content and tries to show the emotional feature of 
each of them. He detected keen understanding of distinctive features of songs, describing mastery of singers - Barbed and Nekis in the "Khosrov and Shirin" and especially their ability to sing with a tender, pleasant voice, melodiously combine and alternate low voices with high, bringing listeners pleasure and joy" [5, p. 154-155]. One of the first, he brought a romance and mystique, epics and folklore in the poem, and most importantly - spoken language, and thanks to this, his works were accessible and understandable to a wide audience, especially among the common people [6]. He treated a word with awe. "The word is a soul or even more alive than soul, because a soul is also valuable to us for the good of the word"; "word pure as a spirit, is an intangible treasure in the treasury"; "that is both new and old, there is a word and there is a word about the words"; " remembrance of the man is a word, except for the word, all the rest is transitory" and many other similar winged words and popular aphorisms about the word are contained in the works of Nizami. Poet repeatedly notes that the word should be treated with caution, because it has many properties - it can "become both tender and fragrant flower, and water of life, returning faith in good, sharp knife that wounded soft tissue of the soul, and red-hot iron, and stones of dirt ... Word can kill and revive, wound and heal, sow confusion and hopelessness - and inspire, dispel doubts; and plunge into depression, generate faith in man and sow distrust, inspire to work - and lead to the soul force rogour" [7].

Nizami understood quite well the therapeutic, magical role of the word; he was a "magician of words" and "mirror of invisible", as he called himself in his works. Of course, ancient culture and philosophy affected the formation of ideology of Nizami as a philosopher, which were widely spread in the Muslim society not only through the Georgian preachers, scholars, but also through the Arab peripatetic school. In the poem "Iskander-Nameh", the philosopher reveals the views of such ancient Greek philosophers as Thales, Socrates, Plato, Aristotle. As noted Azerbaijani scholar Jamal Mustafayev, "Nizami interest in the ancient Greece was due, above all, to social orientation of his world outlook: the poet-philosopher aspired to poeticize and glorify the past of Greece, in order to oppose the ancient democracy to contemporary medieval social order. In addition, the interest of Nizami in the ancient Greece can be explained by the fact that he was looking for an answer in the ancient Greek scientists and philosophers to the questions of the universe he was interested in. It is no accident that Nizami ... gives the statements of Thales, Socrates, Plato, Aristotle, Porphyry and others about the origin and structure of the universe" [5, p.97]. He glamorizes the philosophy of Plato and Aristotle. It should be noted that the ideas of these philosophers are transmitted in scattered and somewhat 
distorted picture, the chronology in respect to these philosophers is not observed, as is noted by many researchers of the poet creative work. "Nizami is very naive to the situation as if all the ancient Greek philosophers and thinkers were living in the age of Aléxandros ho Mégas" [5, p.97-98]. This means that a poet addressed not directly to the works of the philosophers themselves, but used a variety of comments, the works of some scholars, which were not distinguished by truthfulness and historical truth.

He widely uses ancient myths and historical legends in his works. In the "Iskander-Nameh", poet demonstrates excellent knowledge of ancient history and geography. In describing the campaigns of Aléxandros ho Mégas, he gives original historical and cultural characteristics of the conquered lands and peoples, without distorting the historical truth, and decorating them with various myths about the "wonders of the universe", and reveals the features of their geographic location [8].

The creative work of Nizami could not be affected by the Eastern mystical teaching - Sufism which was widely spread in his time, the main purpose of which was "the way to the truth, the only means of transport on which is love" [9]. In his works, he does not deny his sympathy and some spiritual closeness to the Sufi world outlook, in particular, and to the doctrine of Ahi Farrukh Zanjani, as is written in several biographies of the poet. It seems that he was not studied in any "tariq" (school), and had not the Sufi masters. This conclusion arises from the analysis of his artistic heritage and poor historical information about him. However, Nizami as mystic poet could not, but addressed to the sacred, symbolic, metaphorical language of Sufism in his works.

Nizami, being a subtle psychologist, a great connoisseur of the human soul, directed the story of his works to the complexity, strengthening of the psychological component of his characters. In them he reveals the human psychology through his temperament, character, and various forms of interpersonal relations. According to the philosopher-poet, this mentality shows in what form the world will be presented, what would be preferred in the human behavior - the human mind and intellect or sensuality and physical strength.

Nizami with the mouths of his characters does not get tired to say that the main trunk line in the human development, in the formation of his world constitutes morality and ethical life. Everything in the world should be governed by moral soul of man, the ratio of good and evil in it. Philosopher Nizami considered soul as the most important component of a man being, which is the carrier of the highest moral values - friendship, 
love, humanity, etc. But how often, evil, evil origin wins this originally good, positive, moral. And if that happens, then operant motives are rooted in the human psyche, in his inner qualities and necessarily in the social environment in which he is formed. This is objectified in the form of the human world as a good, moral, humane world, revealing the transcendent, divine, absolute as his personal as his own world.

But if not, if the divine principle is not shown, does not wake up in the soul of a man, then, according to Nizami, such a man has the world which is inferior, one-sided and disjunctive. Hence, the researchers of philosopher-poet creative work can conclude that Nizami casts in the huge role in the formation of the human world, moral, not immoral world, to the man himself, his self-awareness. "Above all sciences, Nizami puts the" wisdom "(Hikmat) - universal intuitive knowledge of the man soul and body, which sufis - mystics and elders- tutors possessed in the East in his time. In the first poem, "The Treasury of Mysteries", his admiration for this wisdom, obviously just now received from the elder, is boundless. But, in the last poem, rising, like Omar Khayyam, to the limited for his time heights of skepticism, he says, that and wisdom is just the highest form of the earth, human knowledge, which is powerless before the death. Where the knowledge ends, begins domain of religion, faith, which the only one can save a man from complete confusion and despair" [5].

Nizami as a lyric poet, as a man of feelings and emotions he acutely experienced all the vicissitudes of the world and man, acutely perceived a pain of another man, and hurried to help another. He saw these collisions with his heart, stated predictions, and prophesied a bright future.

He was a true folk poet, singer justice. In his works, with a warmth and tenderness it depicts ordinary people, artisans and craftsmen, sculptors and musicians. With pain poet describes and powerless position of beggars, destitute people who worse than cattle must drag out their natural miserable existence. All sympathies of Nizami are on the side of the working people.

"Dust eat, but do not eat bread of misers!

You are not a dust! Do not let violate yourself by scoundrels.

Thorns stick entirely into the heart and hands,

Do not resign to fate, get down to work.

It's better to get used to any work

Not to come cap in hand to somebody", - writes a poet [1].

The thought of life and death is common thread running through all his works. He compares the life with the fire flashing, death - with its extinction: "If you make breathing closer to the fire, it will break out. If you put the fire into the water, it will become extinct." As the researchers note, 
"comparing death with extinct fire - is not the only case in the history of the philosophy of the East. In this regard, we want to bring the words of the great ancient Chinese philosopher Van Chung, who said, "Death is like the extinguished fire. The nature may again and again, because of the natural development, produce a fire, but it can not force the extinguished fire to blaze up again. Similarly, the nature can continuously give birth to people, but it can not revive and transform a dead body into the spirit." If this view of Van Chung compare with the considered view of Nizami we will see that between them there is a great similarity" [5, p.68-69]. The philosopher rejects a view on the existence of life after death, heaven and hell. Through the words of his hero - Indian sage, he writes:

"Another time, said: tell me the truth,

Why there is a division of the world into two parts

("the terrestrial world" and "the next world"):

With such a beautiful world,

Why would we want another world?

As long as you can live here,

Why should we move to another world?

If asylum is prepared in the next world,

Why then we first came into this world" [1].

Poet and philosopher repeatedly emphasizes that death is the end of human existence. No need to entertain yourself with the illusions of the beyond, and you need to enjoy the pleasures of the world's material existence, creature comforts. However, Nizami, despite the optimism and buoyancy, by calling for philanthropy, for happiness, for glorifying the joys of life on earth - wine, love, fun - yet with a certain dose of pessimism approaches to solve these problems, especially those related to social inequality. All his sympathies are on the side of the underdogs, laborers and craftsmen. "Do not make harm to the people destituted by fate so that their arrow of loud curses could not get you" - with these words poet appeals to the Shah in the poem "The Treasury of Mysteries." How to make commons happy? This question in a different setting, at a different angle of view puts the poet-philosopher in his works. And it remains open as Nizami is unable to respond to it:

"Be drowned in tears, Nizami, depressed with such trouble,

Shed floods of tears over the heart so that blood became water" [1].

Philosopher and humanist advised people to get rid of ignorance, cruelty, greed, and other negative qualities and played for the exercise of genuine humanistic moral principles. This has been most evident in the poetry of the poet-philosopher. 
Apogee of his poetic work was reached in "Khamsa" ("Panj Ganj" in Persian language means "Five Treasures"), consisting of five poems, each of which is a separate finished work. Following the established Eastern tradition, Nizami devoted his poems to the rulers. The poem "Treasury of Mysteries" ("Mahsan al-Asrar") he devoted to the governor Erzinjan Fakhr ad-Din Bahram Shah (1155-1218). The poem "Khosrow and Shirin" is devoted to Seljuk Sultan Togrul 111 (1175-1194), atabek Muhammad ibn Eldigiz Jahan Pahlavan (1175-1186) and his brother Kyzyl-Arslan (11861191). The poem "Layla and Majnun " Nizami devoted to Shirvanshahs, "Seven Beauties" - to atabek Maraghi Ala al-Din who was the rival of Ildegizids, "Iskander-Nameh" - to malekh Ahar Nosrat bin Mohammad of Pishkinid dynasty (1155-123) [8]. The cementing foundation of his poems, especially of three poems - "Layla and Majnun ", "Khosrow and Shirin" and "Seven Beauties" - is love, which is considered by Nizami not as the relationships between You and Me, but as the highest spiritual form of a man, taking the nature of high spirituality. It is this spirituality that characterizes a human.

His poems are truly ambitious. They are some kind of informative generators, encyclopedia of the life of people of the whole age. They contain valuable ethnographic and everyday material from the life of people of hoary antiquity of the middle ages. Therefore, his poems are unique because they are the source of knowledge about those distant times, mankind times immemorial for the next generation. For example, thanks to his poems, we have a fair view of the Persian and Azeri musical creativity and musical instruments of the XII century. He tells about famous musicians of his time, gives a detailed description of the musical instruments. He left the information of spiritual and cultural character as well, including the way of life and customs of different social groups. His works also contain descriptions of material culture monuments - the palaces, large mosques, mausoleums, caravanserais, etc., a few of which have survived to this day. The content of his poems also includes the collection of tales and stories of different peoples of the world, and folklore of the ancient world [8].

Nizami created a tradition of new Turkic literature, which later had a decisive role in the genesis of Turkic literature.

Creativity of Nizami is permeated with a high humanism. Seeing the essence of human nature in its moral possibilities, the humanism of the poetphilosopher requires from each person unconditional love and respect for the other person. A should see in another man only the supreme goal, absolute value, but should never turn the other man into a tool to achieve his goals. Moreover, under the conditions of medieval society, Nizami urges the 
rulers to appreciate a man for his soul and spiritual qualities, in spite of his appearance and color. "The Negro has a black skin, but clean soul" - he writes in his poem "Iskender-nameh."

Man is responsible to society for what moral qualities he embodies in his behavior, how he fulfills his high purpose - to be a man. But in turn, the society is also liable to a man: what conditions it creates for his development, improvement, for the manifestation of his creative powers.

It is clear that the moral crisis in any society looks deterrent. A man turns out to be at dead end. In such situation, the increase of violence as a means of resolving the protracted conflict between the individual and society is not surprising. What can be opposed to this process? - These are the values of good, self-respect and human dignity.

Nizami shows that the world of values is ambiguous. The dialectics of their development is not simply a substitution by each other. Rather, they resemble the Russian dolls nested one into another, each of which is an addition to the other, which collectively form a unified and complete structure of the human spiritual world.

Values are the expression of significance of something for a man. It is a way of life orientation, which gives meaning to different deeds and actions, or life in general. Since values are not equal, their choice depends on the moral character of the individual. The foundation of the moral qualities forms a dignity ("how to be"), honor ("how to be said") and conscience ("how to evaluate meself"). Their own value is determined by how a person is self-reliant in a situation of selection. Finally, this ability to make choice is formed not spontaneously, but purposefully. It consists of going beyond the frames of empirical reality. This is creativity. Selfaffirmation in a free activity is the highest form of creativity. What is happening at this time with morality? It turns from external regulator of human behavior into the inner conscious autonomy. The starting point in this process is the spiritual freedom of the individual. This does not mean, however, that a value approach to the reality creates any kind of human activity. First, it appears historically, i.e., is determined by the needs of society. Second, it is given by the level of the individual development. The variety of ongoing processes shows that nothing is for free to a man or society. Both high level of material well-being and excessive struggle for basic living conditions do not facilitate the spiritual growth, if a man himself does not think about the meaning of such concepts as peace, good and evil, love and happiness which give a meaning to his existence. The value of individual Nizami sees in the usefulness of his work results for the benefit of people and society: 
"Do not try to avoid people like magician.

Keep company with people if you are a man,

Because a man is glad to associate with a man.

If you are a precious treasure, and do not yield to somebody,

Then there aree many such treasures under the ground.

If the tree is away from the one who eats the fruit,

Does it matter where the fruits or spikes are there?" [1].

The relations between the people become harmonious when they reach such a degree of transparency in which the good is directly exchanged for good, trust for trust, mediating nor by money, family ties, or secret expectation for further services. These and other ideas, views of Nizami on many issues of morality, humanity, all-round and harmonious development of the individual preserve their intrinsic value to the present day as well.

Conclusion. Poetry of Nizami had a great influence on the formation and development of poetic talent, craftsmanship of many outstanding genius of the pen, both of his era and beyond. Already in the medieval times, the Turkic readers with great interest acquainted with the work of his illustrious poet and philosopher Nizami through the work of some Turkic poets imitating his poems and writing original poetry answers to them. Among them are dozens of Nazire (poetic "answers") and imitations of the poems "Hamse" that were created from the XIII century, and belonged, in particular, to such famous poets as Alisher Navoi, Amir Khosrow Dehlevi and others. For example, the Persian scholar Hekmet compiled a list consisting of forty Persian and thirty Turkish versions of the poem "Layla and Majnun" [8].

Creativity of Nizami had alaso a great influence on the development of Persian literature. Expressive data about this influence in part were left by the Russian scientist of the XIX century G.Spassk-Avtonomov, who was sent to Tehran to study Persian. He writes that "among the poets, Persian critics above all glorify Nizami", who was "Sufa - that is mystic." In Persia, the poets Saadi, Firdowsi, Anwari are called prophets, and Nizami - a god among the poets, - he says. In this he explains his special interest in the work of Nizami, especially in "Hamse." Indeed, "Hamse" were a model of not only imitations for many generations of poets of the East, but also gave an abundance of creative material for artists, especially enriched the art of miniature. It should be noted that the works of Nizami exceed the number of illustrated works of Persian literature.

At different times, many well-known representatives of art of foreign countries took the plots of Nizami's poems as a basis for the direction and performance of films, plays, operas, ballets. This is striking example and 
illustration of the world fame of brilliant works of Nizami and their vitality through the centuries. So, on the plot of the poem "Seven Beauties" ("Haft peykar") of Nizami, the Italian composer Giacomo Puccini wrote the opera "Turandot", the first performance of which was held in Milan on April 25, $1926[8]$.

Creativity of Nizami served and serves as an inexhaustible wellspring for Azerbaijani cultural figures. Composers have repeatedly appealed to creativity and to the image of Nizami, such as Niazi (chamber opera "Khosrow and Shirin", 1942), Fikret Amirov (Symphony "Nizami", 1947), Afrasiyab Badalbeyli (opera "Nizami", 1948). Soviet composer Kara Karayev twice appealed to the plot of "Seven Beauties": first, he wrote a symphonic suite of the same name (1949), and then, in 1952 - the ballet "Seven Beauties", which brought the world fame to the composer. A film of Azerbaijani studio "Layla and Majnun " was shot (1961) on the basis of similar works of Nizami and Füzuli. Five films of Azerbaijani cinematographers were devoted to Nizami, including feature film "Nizami" (1982) with Muslim Magomayev in the key role [8].

Nizami, in spite of what I have written many centuries ago, as modern and relevant, as in the times of the philosopher-poet. Poetry Nizami has vital, optimistic character; it can see not only the bitterness of life, but also her joy [10]. His poetry does not have the time; its place is here and there. Justly about this says the poet-philosopher Nizami himself:

"If you ask a century later, where is he?

Each line of the poet will respond like an echo: he is here!" [1].

\section{References}

1. Nizami. Five poems. Library of World Literature. Series one. M., Publishing house "Khudozhestvennaya literatura", 1968.- 345 p.

2. Khalil Yusifli. Renaissance and Nizami Ganjavi. Baku, "Elm ve tehsil", 2016. - 426 p.

3. Shukurova G.V. Jafar Khandan about the work of Nizami Ganjavi. // Zh-1

"Philological sciences. Questions of theory and practice ". Tambov: Diploma, 2019. Volume 12. Issue 10. P. 87-91.

4. Bertels E. Nizami. Young guard. 1948 .-- 262 p.

5. Jamal Mustafayev. Philosophical and ethical views of Nizami. Baku, 1962 .-- 234 p.

6. Bertels E. The great Azerbaijani poet Nizami. Era - Life - Creativity. Publishing house AzFAN. Baku - 1940.-147 s.

7. Sukhomlinsky A.V. The science of winning. Pedagogical works. M., "Education", 1975. - $291 \mathrm{p}$.

8. Electronic resource: http://azeribook.com (History of Azerbaijan). - Date of treatment: 10/13/2021.

9. Sufism in the context of Muslim culture. M., "Science", 2019. - 372 p.

10. Krymskiy A.E. Nizami and his contemporaries. Baku: "Elm", 1981. - 247 p. 
Özet

$\mathrm{Bu}$ makalede, Nizami Gencevi'nin eğitim anlayışındaki etik görüşleri ele alınmıştır. Büyük Azerbaycan şairi ve düşünürünün dünya maneviyat tarihindeki yeri ve rölü dile getirilmiştir. Toplumdaki her bireyin manevi gelişmesine ve hümanistik yolda ilerlemesine katkıda bulunan Nizami'nin manzum eserlerinin özellikleri ve özgünlüğü analiz edilmiștir. Şair, insanın yaşamındaki en önemli kişiliklerden dostluk, sevgi, insanlık gibi v.b özelliklerinin sahibi onun ruhu olduğu görüşünü savunmuştur. Onun "Hamse" adlı nazım örneğinde iyilik, gaddarlık, zalimlik, mutluluk ve hayatın önemi gibi ahlaki kategoriler incelenmiştir. Şair Nizami, bir hümanist olarak insan psikolojisinin inceliklerini ve ruhunun mükemmelliğine önem vermeye ve bunu çalışmalarında ortaya çıkarmaya çalışmıştır. Ahlak, insanın manevi gelişiminde ilkel çizgilerden sayılmaktadır. Bu görüss, Nizami Gencevi'nin eserlerinde daha net görülür. Onun çalışmalarında insan maneviyatın, emeğin, halk kültürünün temcilcisi olarak tasvir edilmiştir. Ayrıca bu çalışmada diğer etik meseleler de ele alınır. Genel olarak Nizami Gencevi'nin bilim dünyasındaki hümanistik ve ahlaki kurallarına yer verilmiştir.

Anahtar Kelimeler: Adalet Yanlısı, Hümanizm, Hamse, Ahlak, Değerler

(K. Begalınova, M. Ashılova, A. Begalınov, Nizami Gencevi'nin Manevi Hümanistik Eğitim Anlayışının Özellikleri)

\section{Аннотация}

В статье раскрывается этический аспект, присущий учению Низами Гянджеви. Рассматриваются роль и место великого азербайджанского поэта и мыслителя в истории мировой духовности. Авторы анализируют самобытность, уникальность поэтического творчества Низами, призывавшего каждого человека к духовному и нравственному самосовершенствованию. Он утверждал, что самым главным составляющим бытия человека является его душа, которая является носителем высших нравственных качеств - дружбы, любви, человечности и др. Главным героем его произведений является народ. Вся симпатия поэта на его стороне. На примере его поэмы «Хамсе» исследуются такие моральные категории, как добро, жестокость, зло, счастье, смысл жизни и др. Немаловажное значение уделяется раскрытию личности поэта-мыслителя Низами как гуманиста, тонкого психолога, великолепного знатока человеческой души. Показывается, что магистральную линию в становлении человека, его духовности играет нравственность. Свидетельством этому являются многочисленные произведения Низами Гянджеви, в которых воспевается человек труда, подлинный носитель духовности, культуры народа. Затрагиваются и другие этические проблемы, изложенные в трудах великого мыслителя. В целом, учение Низами Гянджеви утверждает подлинно гуманистические моральные принципы в обществе.

Ключевые слова: сказитель справедливости, гуманизм, «Хамсе», мораль, ценности

(К. Бегалинова, М. Ашилова, А. Бегалинов. Особенности духовно-нравственного учения Низами Гянджеви) 